\title{
Characterization of High Temperature Deformation Behavior of BFe10-1-2 Cupronickel Alloy Using Constitutive Equation and Processing Map
}

\author{
Cai Jun, Wang Kuaishe, Wang Wen \\ Metallurgy Engineering Technology Research Center of Shaanxi, Xi'an University of Architecture and Technology, Xi'an 710055, China
}

\begin{abstract}
High temperature deformation behavior of BFe10-1-2 cupronickel alloy under compression in the temperature range of 1023 1273 K and strain rate range of $0.001 \sim 10 \mathrm{~s}^{-1}$ was investigated to acquire the optimum hot deformation processing parameters. The high temperature deformation behavior of BFe10-1-2 cupronickel alloy was characterized based on the analysis of the flow stress, kinetics and processing map. The activation energy for deformation obtained during high temperature compression of BFe10-1-2 cupronickel alloy was $425.299 \mathrm{~kJ} / \mathrm{mol}$. A constitutive equation was then developed to describe the flow stress as a function of Zener-Holloman parameter and true strain. By comparing the calculated flow stress and the measured flow stress, the constitutive equation was verified. The results show that the flow stress values obtained from the constitutive equation could track the experimental results. Thereafter, the processing map based on dynamic materials model was established, and the validation of processing map was investigated from the macro appearance and microstructure of compressed BFe10-1-2 cupronickel alloy.
\end{abstract}

Key words: BFe10-1-2 cupronickel alloy; high temperature deformation behavior; constitutive equation; processing map

As a typical $\mathrm{Cu}-\mathrm{Ni}$ alloy, BFe10-1-2 alloy has been widely employed as pipelines, structural materials and ship hulls in marine environments because of the excellent corrosion resistance and anti-fouling properties ${ }^{[1]}$. Nowadays, cupronickel alloys are commonly produced by semi-solid casting ingots and hot extrusion, which result in a lot of problems, such as long process time, high energy consumption, low product yield and high cost. Designers of metal forming processes are eager to understand how metal materials behave under hot working conditions ${ }^{[2]}$. Hence, it is of vital significance to understand its high temperature deformation behavior, and thus we can design the suitable deformation parameters.

Flow stress is one of the most important fundamental performance indicators for the hot deformation process, which determines the load and energy needed during the plastic deformation ${ }^{[3]}$. As is well known, an constitutive equation is a powerful tool that can predict the flow behaviors of materials ${ }^{[4]}$. Based on the dynamic materials model (DMM), processing maps can be constructed to determine the optimum conditions during high temperature deformation processes ${ }^{[5]}$. Many researchers have attempted to use processing maps with a wide range of materials ${ }^{[6-13]}$. However, there are few researches on the high temperature deformation behavior and workability of BFe10-1-2 cupronickel alloy. Therefore, the main objective of the present paper was to investigate the plastic flow behaviors of BFe10-1-2 cupronickel alloy. Toward this end, isothermal hot compression tests were conducted in the temperature range of $1023 \sim 1273 \mathrm{~K}$ and strain rate range of $0.001 \sim 10 \mathrm{~s}^{-1}$. Then the constitutive equation and the processing map for BFe10-1-2 cupronickel alloy material were developed to optimize processing parameters.

\section{Experiment}

Received date: October 20, 2015

Foundation item: Planned Scientific Research Project of Education Department of Shaanxi Provincial Government (15JS056); Pre-research Foundation of Jinchuan Company-Xi'an University of Architecture and Technology (YY1501)

Corresponding author: Cai Jun, Ph. D., lecturer, Metallurgy Engineering Technology Research Center of Shaanxi, School of Metallurgical Engineering, Xi'an University of Architecture and Technology, Xi'an 710055, P. R. China, Tel: 0086-29-82202938, E-mail: caijun@xauat.edu.cn 
The chemical composition (wt\%) of BFe10-1-2 cupronickel alloy investigated in the present study is: $\mathrm{Ni10.80}, \mathrm{Mn} 2, \mathrm{Fe} 1.38, \mathrm{Cu}$ bal. And the original microstructure of as received BFe10-1-2 cupronickel alloy is shown in Fig.1. Cylindrical specimens were machined with a diameter of $10 \mathrm{~mm}$ and a height of $15 \mathrm{~mm}$ for compression tests. The flat ends of each specimen were recessed by a depth of $0.1 \mathrm{~mm}$ groove to entrap the lubricant for the purpose of minimizing the friction. Each specimen was heated to the deformation temperature at a rate of $10{ }^{\circ} \mathrm{C} / \mathrm{s}$, and held for $3 \mathrm{~min}$ under the isothermal conditions before compression tests. After deformation, the specimens were cooled to room temperature in air, and the strain-stress curves were recorded automatically in isothermal compression.

To observe the microstructure, the compressed specimens were axially sectioned and prepared by standard metallographic techniques, and the position for $\mathrm{OM}$ observation was illustrated in Fig.2 (Position 1).

\section{Results and Discussion}

\subsection{Flow stress}

Fig.3 demonstrates the obtained flow curves under different deformation conditions. It can be seen that the flow stress increases with decrease of the deformation temperature and increase of the strain rate. At the initial stage, the flow stress increases with the increase of deformation. Subsequently, there is a slow flow softening stage with the increase of strain, followed by a steady-state flow at the

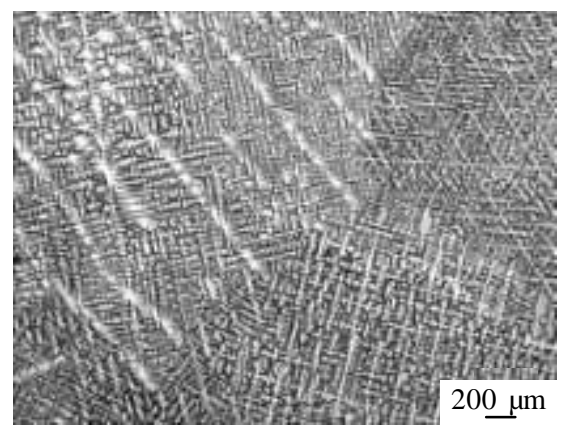

Fig.1 Original optical microstructure of as received BFe10-1-2 cupronickel alloy

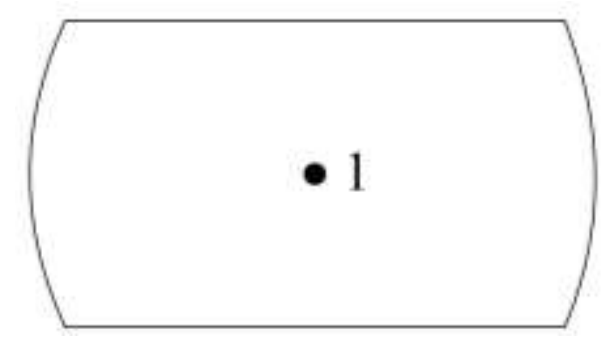

Fig.2 Position of OM observation for compressed specimen
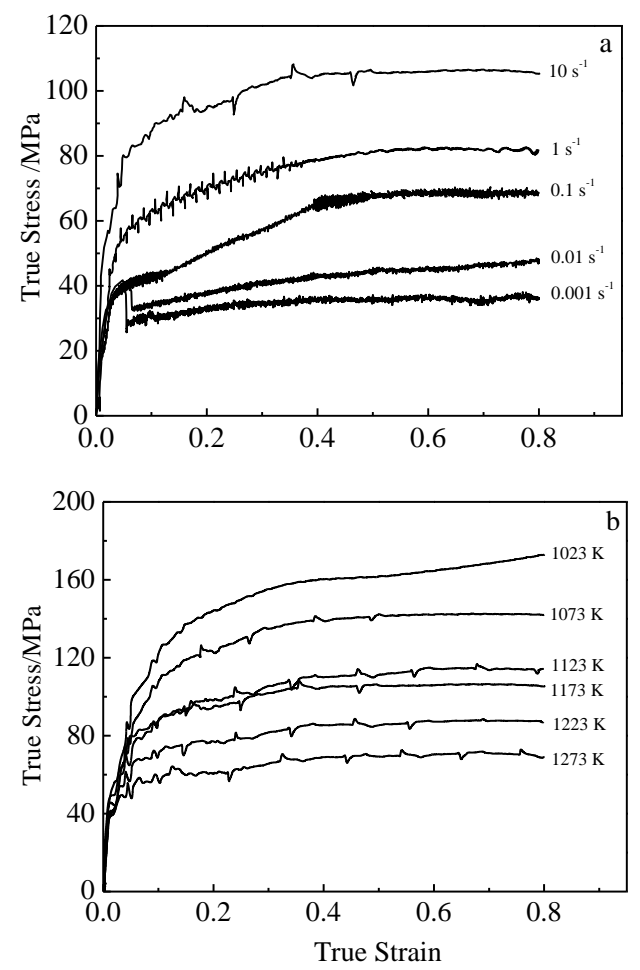

Fig.3 Flow curves of BFe10-1-2 cupronickel alloy obtained under various deformation conditions: (a) $1173 \mathrm{~K}$ and (b) $10 \mathrm{~s}^{-1}$

large strain. Theoretically, the deformation at high temperature is presented as the competing process of dynamic softening (DS) and work hardening (WH). At the beginning of deformation, the dislocation density increases rapidly, leading to the increase of flow stress. Subsequently, with increasing of the strain, the dislocation density in subgrains reaches to a stable level because of dislocation annihilation and recombination, which slows down the rate of work softening due to DS. When the WH and DS reach a dynamic equilibrium, the dislocation density remains relatively constant, and the flow stress tends to be a steady value. It can be seen from Fig. 3 that the flow stress increases monotonically with the increase of strain under some deformation conditions, and the rate of flow stress rising decreases with the increase of strain. According to the dynamic recrystallization (DRX) mechanism during hot deformation process, the flow stress will exhibit a peak stress due to the occurrence of recrystallization, and then the flow stress will decrease until it reaches a steady stress. However, there is no peak stress in Fig.3, only indicating the occurrence of DRV during the deformation process. Furthermore, a sudden drop can be observed in flow stress at the early stage for low strain rates $\left(0.01\right.$ and $\left.0.001 \mathrm{~s}^{-1}\right)$, as shown in Fig.3a. Similar flow stress drop was reported by Lin in BFe10-1-1 and BFe30-1-1 cupronickel alloy at the strain rates of 10 and $20 \mathrm{~s}^{-1[14,15]}$, and $42 \mathrm{CrMo}$ steel at the 
strain rates of 10 and $50 \mathrm{~s}^{-1}{ }^{[16]}$. Further research needs to be done to draw a firm conclusion.

The peak stress values of BFe10-1-2 cupronickel alloy during isothermal compression are shown in Fig.4. It can be found from Fig.4 that the peak stress decreases with increasing of the deformation temperature, and increases with the increase of strain rate. The overall increase at lower strain rates has no obvious difference with that at high strain rates. This phenomenon shows a significant difference with those of some titanium alloys, in which the increase of peak stress is relatively small for low strain rate values and it rises with increase of strain rate owing to DRX ${ }^{[17,18]}$.

\subsection{Kinetic analysis}

The dependence of flow stress on the strain rate and temperature at high temperatures can be expressed in terms of a kinetic equation:

$$
\dot{\varepsilon}=A F(\sigma) \exp \left(-\frac{Q}{R T}\right)
$$

where $\dot{\varepsilon}$ is strain rate $\left(\mathrm{s}^{-1}\right), R$ is the universal gas constant $\left(8.314 \mathrm{~J} \cdot \mathrm{mol}^{-1} \cdot \mathrm{K}^{-1}\right), T$ is the absolute temperature $(\mathrm{K})$ and $Q$ is the activation energy of hot deformation $(\mathrm{J} / \mathrm{mol})$ that can be obtained from following equations:

$$
Q=R n \frac{\mathrm{d}\{\ln [\sinh (\alpha \sigma)]\}}{\mathrm{d}(1 / T)}
$$

where $\alpha=\beta / n^{\prime}$, and $\frac{1}{\beta}=\frac{\partial \sigma}{\partial \ln \dot{\varepsilon}}, \frac{1}{n^{\prime}}=\frac{\partial \ln \sigma}{\partial \ln \dot{\varepsilon}}$ and $\frac{1}{n}=\frac{\mathrm{d}\{\ln [\sinh (\alpha \sigma)]\}}{\mathrm{d}(\ln \dot{\varepsilon})}$. Therefore, $Q$ can be obtained from the slops of lines of $\ln [\sinh (\alpha \sigma)-1 / T]$, and the mean value of $Q$ obtained from different strains is taken as that of activation energy for BFe10-1-2 cupronickel alloy, which can be calculated to be $425.299 \mathrm{~kJ} / \mathrm{mol}$. Zener-Holloman parameter $(Z)$ is introduced to describe the relationship between strain rate and deformation temperature:

$$
Z=\dot{\varepsilon} \exp \left(\frac{Q}{R T}\right)
$$

Thereafter, Eq.(1) can be changed into the following formula ${ }^{[17]}$ :

$$
\ln \sigma=B_{0}+B_{1} \ln Z+B_{2} \ln \varepsilon
$$

The values of $B_{2}$ can be obtained from the slope of the lines in $\ln \sigma-\ln \varepsilon$. And $B_{0}$ and $B_{1}$ can be obtained from the slope and intercept of the curves in $\left(\ln \sigma-B_{2} \ln \varepsilon\right)-\ln Z$. The results of $B_{0}, B_{1}$ and $B_{2}$ of BFe10-1-2 cupronickel alloy are provided in Table 1.

The developed constitutive equation of BFe10-1-2 cupronickel alloy at elevated temperatures is verified by comparing the experimental and the predicted flow stress data, as illustrated in Fig.5. It can be found that the predicted flow stress values from the constitutive equation can track the experimental data of BFe10-1-2 cupronickel alloy under most deformation conditions. It is concluded

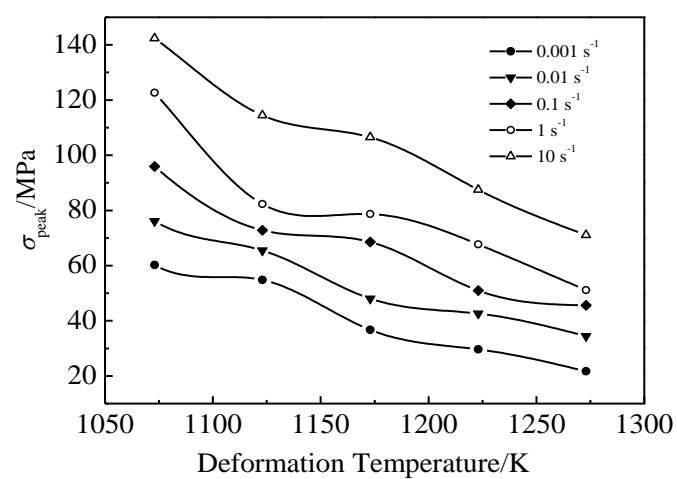

Fig.4 Peak stress in the isothermal compression of BFe10-1-2 cupronickel alloy

Table 1 Constants of BFe10-1-2 cupronickel alloy in Eq. (4)

\begin{tabular}{cccc}
\hline Temperature/K & $B_{0}$ & $B_{1}$ & $B_{2}$ \\
\hline$\leq 1123$ & 0.6461 & 0.08645 & \\
$>1173$ & -0.7378 & 0.1197 & 0.1352 \\
\hline
\end{tabular}
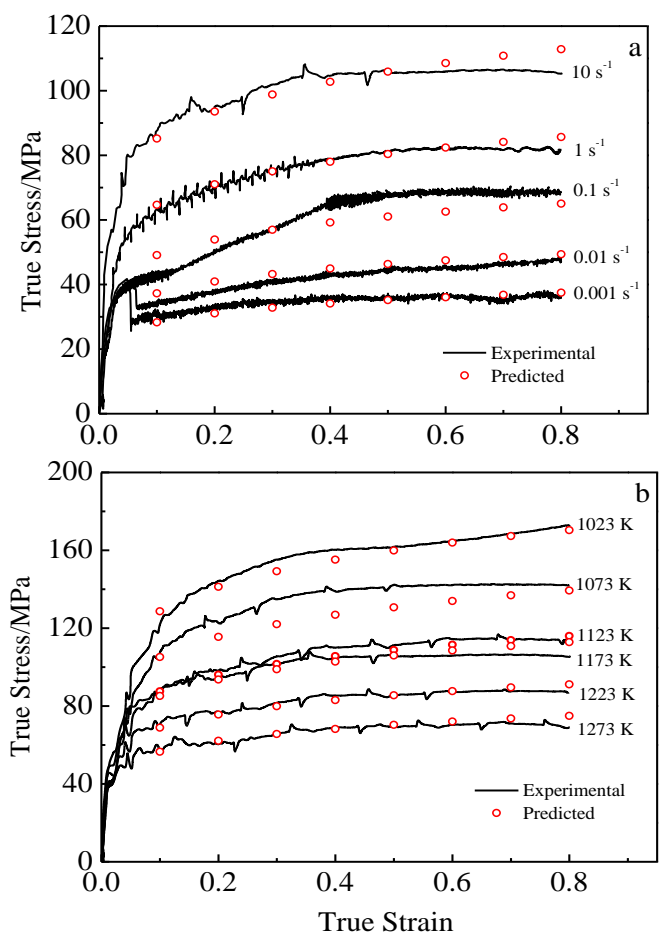

Fig.5 Comparison between the experimental and the predicted flow stress at the temperature of $1173 \mathrm{~K}$ (a) and the strain rate of $10 \mathrm{~s}^{-1}(\mathrm{~b})$

that the constitutive equation with high prediction precision can be used to describe high temperature flow behavior of BFe10-1-2 cupronickel alloy.

\subsection{Processing map}

The processing map based on DMM is widely used for optimizing the hot working processing parameters. According to the DMM, the mechanical process is considered as a power dissipation system, and the 
characteristics of power dissipation through microstructural changes are expressed in terms of an efficiency of power dissipation $\eta$, which is defined as ${ }^{[19,20]}$ :

$$
\eta=\frac{2 m}{m+1}
$$

where $m$ is the strain rate sensitivity parameter, and $m=\partial \ln \sigma / \partial \ln \dot{\varepsilon}$. Therefore, $\eta$ is a dimensionless parameter, which characterizes the efficiency of the energy dissipation by microstructure evolution during hot deformation. The instability criterion is given as ${ }^{[20]}$ :

$$
\xi(\dot{\varepsilon})=\frac{\partial \ln \left(\frac{m}{m+1}\right)}{\partial \ln \dot{\varepsilon}}+m<0
$$

Then, the processing map of BFe10-1-2 cupronickel alloy is obtained by superimposing the instability map on the power dissipation map. Fig.6 illustrates the processing map for BFe10-1-2 cupronickel alloy at strain of 0.8. The contour numbers in the figure indicate the efficiency of power dissipation $\eta$. The dashed and non-dashed domains represent the flow instability and reasonable deformation regions, respectively. Generally, high efficiency of power dissipation indicates an optimal deformation condition. However, the high efficiency of power dissipation does not necessarily indicate the good workability, because some variations of instability such as wedge crack may occur at this region. Therefore, only those deformation conditions corresponding to both the high efficiency and stability regions in processing map can be regarded as the suitable hot working parameters ${ }^{[21]}$.

It can be seen from Fig.6 that this alloy exhibits three instability domains: (I) the first is at the deformation temperatures from $1023 \mathrm{~K}$ to $1116 \mathrm{~K}$ and the strain rates from 0.61 to $10 \mathrm{~s}^{-1}$; (II) the second is at the deformation temperatures from 1095 to $1175 \mathrm{~K}$ and the strain rates from 0.001 to $0.033 \mathrm{~s}^{-1}$; and (III) the third is at the deformation temperatures from 1190 to $1273 \mathrm{~K}$ and the strain rates from 0.004 to $0.257 \mathrm{~s}^{-1}$, indicating a hard working ability of BFe10-1-2 cupronickel alloy.

Fig.7 shows the representative macro appearance and microstructure of $\mathrm{BFe} 10-1-2$ cupronickel alloy at the temperature of $1073 \mathrm{~K}$ and strain rate of $10 \mathrm{~s}^{-1}$, corresponding to the instability domain of position I in Fig. 6. It can be seen from Fig.7a that the specimen after high temperature compression exhibits evident inhomogeneous deformation (red arrows in the figure). The microstructure of the specimen shows that high strain rate and low temperature lead to the flow localizations (red arrows in Fig.7b). It may be attributed to the fact that the insufficient time of plastic deformation causes a reduction in the flow stress locally with further straining, and consequently slip becomes localized. As is well known, high values of $\eta$ or $m$ can reduce the tendency for flow localization. Fig.8 shows the iso-efficiency contours of $m$ map. It can be seen from
Fig. 6 and Fig. 8 that the values of $\eta$ and $m$ are lower than 0.1 and 0.06 , respectively, which indicate most of the plastic

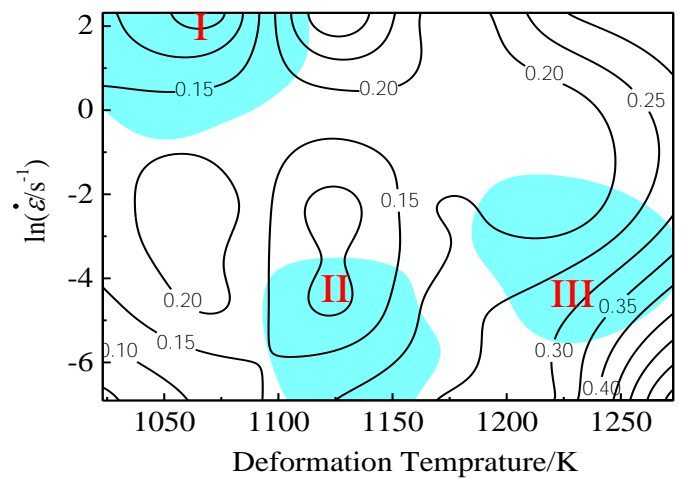

Fig.6 Processing map of BFe10-1-2 cupronickel alloy at strain of 0.8

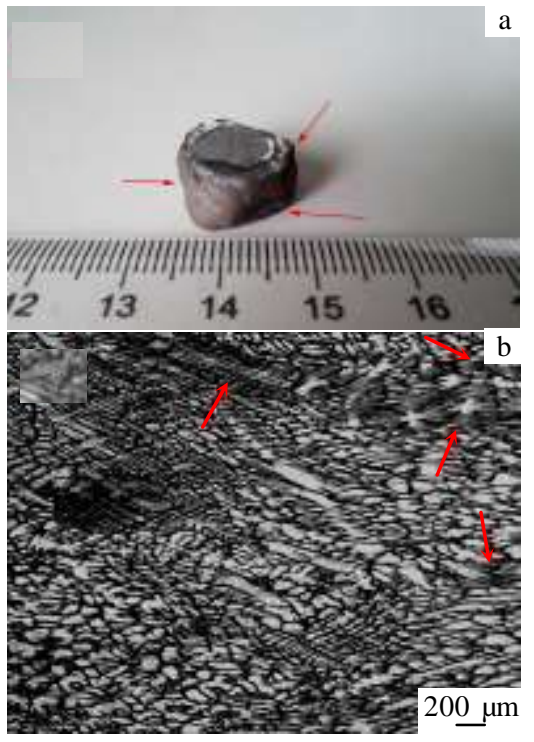

Fig.7 Macro appearance (a) and microstructure (b) of BFe10-1-2 cupronickel alloy at the temperature of $1073 \mathrm{~K}$ and strain rate of $10 \mathrm{~s}^{-1}$

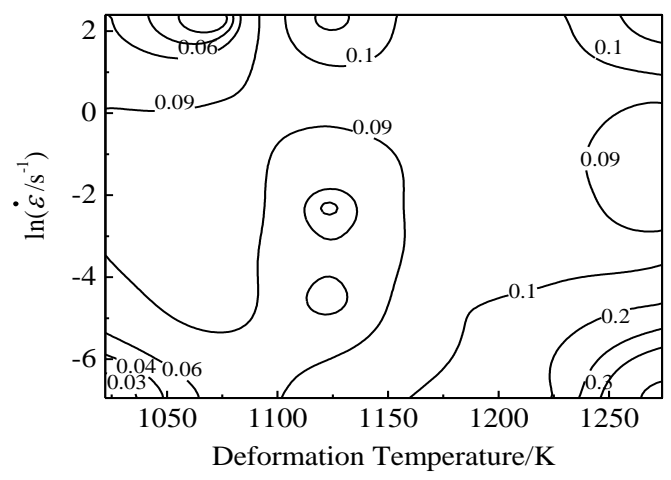

Fig.8 Contour map of $m$ at the strain of 0.8 
power is converted to heat and dissipated in the form of temperature rise. Therefore, the material has a poor workability under this deformation condition.

Microstructures of BFe10-1-2 cupronickel alloy at the $1123 \mathrm{~K}, 0.01 \mathrm{~s}^{-1}$ and $1223 \mathrm{~K}, 0.01 \mathrm{~s}^{-1}$ are given in Fig.9 and Fig.10, respectively, corresponding to the instability domain of position II and III in Fig.6. From Fig.9, it can be seen that flow localization (red arrows) appears in the specimen after compression at the temperature of $1123 \mathrm{~K}$ and strain rate of $0.01 \mathrm{~s}^{-1}$. Meanwhile, the efficiency of power dissipation $\eta$ is lower than 0.11 (shown in Fig.6), and strain rate sensitivity $m$ is lower than 0.09 (shown in Fig.8). Hence, this region should be avoided during high temperature deformation.

From Fig.10, it can be observed that flow localization (red arrow) and the exceptional grain growth (blue arrows) appear in this instability domain at a deformation temperature of $1223 \mathrm{~K}$ and strain rate of $0.01 \mathrm{~s}^{-1}$. Similar exceptional grain growth was reported by Luo ${ }^{[22]}$ in Ti-6Al-4V alloy at the deformation temperature of $1183 \mathrm{~K}$ and strain rate of $0.1 \mathrm{~s}^{-1}$, indicating the sound high temperature deformation should not be performed in this domain. Meanwhile, only deformed flat grains can be observed at Fig.9b and Fig.10b, but no equiaxed DRX grains can be detected. Furthermore, the peak efficiency of power dissipation locates in the deformation temperature range of 1226 to $1273 \mathrm{~K}$ and strain rate range of $0.004 \mathrm{~s}^{-1}$ to $0.001 \mathrm{~s}^{-1}$, which is correspondent to an optimal deformation condition for BFe10-1-2 cupronickel alloy.

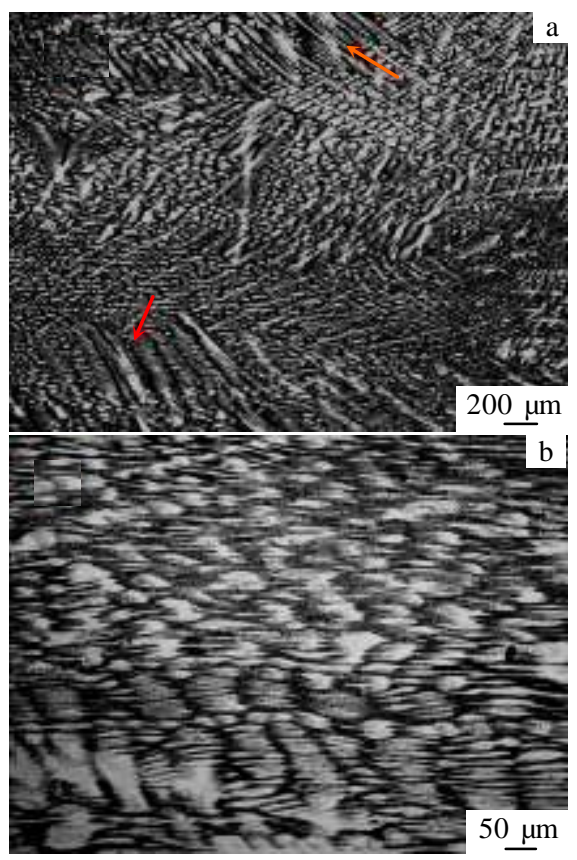

Fig.9 Microstructures of BFe10-1-2 cupronickel alloy at temperature of $1123 \mathrm{~K}$ and strain rate of $0.01 \mathrm{~s}^{-1}$ : (a) low magnification and (b) high magnification

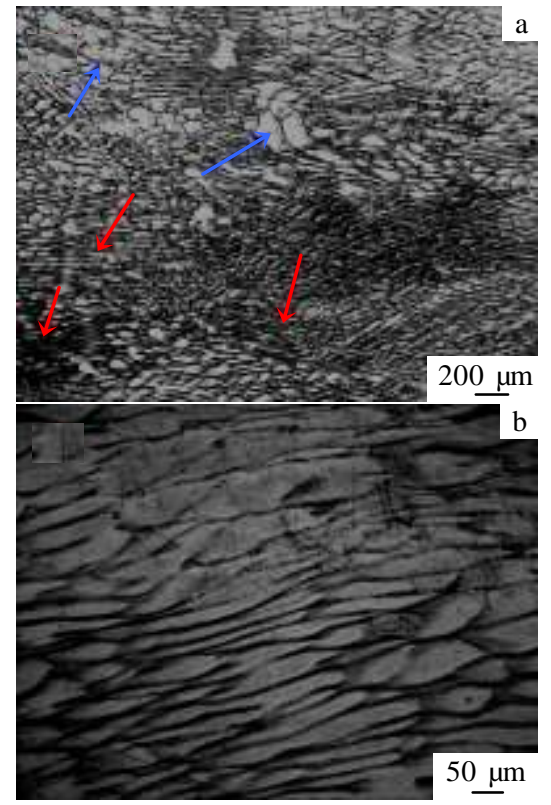

Fig.10 Microstructures of BFe10-1-2 cupronickel alloy at temperature of $1223 \mathrm{~K}$ and strain rate of $0.01 \mathrm{~s}^{-1}$ : (a) low magnification and (b) high magnification

\section{Conclusions}

1) The flow stress of BFe10-1-2 cupronickel alloy is significantly affected by deformation temperature and strain rate, namely, the flow stress decreases with the increase of the deformation temperature and the decrease of the strain rate. Meanwhile, the flow stress curves exhibit the typical DRV characteristics.

2) The apparent activation energy $Q$ of BFe10-1-2 cupronickel alloy is calculated to be $425.299 \mathrm{~kJ} / \mathrm{mol}$, and a constitutive equation by which the flow stress is represented as a function of Zener-Holloman parameter and strain has been developed. The result reflects the good prediction capabilities of the developed constitutive equation for BFe10-1-2 cupronickel alloy.

3) The processing map reveals that BFe10-1-2 cupronickel alloy exhibits three instability domains: (I) the temperature range from $1023 \mathrm{~K}$ to $1116 \mathrm{~K}$ and the strain rate range from $0.61 \mathrm{~s}^{-1}$ to $10 \mathrm{~s}^{-1}$; (II) the temperatures range from $1095 \mathrm{~K}$ to $1175 \mathrm{~K}$ and the strain rate range from 0.001 to $0.033 \mathrm{~s}^{-1}$; (III) the temperature range from $1190 \mathrm{~K}$ to $1273 \mathrm{~K}$ and the strain rate range from $0.004 \mathrm{~s}^{-1}$ to $0.257 \mathrm{~s}^{-1}$. Microstructural examination shows that these regions should be avoided during hot deformation. Moreover, optimum hot working domain of the alloy is the deformation temperature range of $1226 \sim 1273 \mathrm{~K}$ and strain rate range of $0.004 \sim 0.001 \mathrm{~s}^{-1}$.

\section{References}


1 Cai J, Wang K S, Miao C P et al. Materials and Design[J], 2015, 65: 272

$2 \mathrm{Yu} \mathrm{H}, \mathrm{Yu} \mathrm{H} \mathrm{S}$, Min G $\mathrm{H}$ et al. Metals and Materials International[J], 2013, 19(4): 651

3 Shi Z X, Yan X F, Duan C H. Journal of Alloys and Compounds[J], 2015, 652: 30

4 Yu H, Yu H S, Kim Y M et al. Transactions of Nonferrous Metals Society of China[J], 2013, 23(3): 756

$5 \mathrm{Yu}$ H, Kim Y M, Yu H S et al. Acta Metallurgica Sinica[J], 2012, 48(9): 1123 (in Chinese)

6 Hao S M, Xie J P, Wang A Q et al. Rare Metal Materials and Engineering[J], 2014, 43(12): 2912 (in Chinese)

7 Huang Y J, Chen Z G. Rare Metal Materials and Engineering[J], 2012, 41(5): 757 (in Chinese)

8 Chen H S, Liu X H, Liu G F et al. Rare Metal Materials and Engineering[J], 2016, 45(4): 901 (in Chinese)

9 Chen Baodong, Guo Feng, Wen Jing. Rare Metal Materials and Engineering[J], 2014, 43(3): 615 (in Chinese)

10 Kan Zhi, Du Linxiu, Hu Jun. Rare Metal Materials and Engineering[J], 2016, 45(2): 363 (in Chinese)

11 Sun Chaoyang, Li Yamin, Xiang Yu et al. Rare Metal Materials and Engineering[J], 2016, 45(3): 688 (in Chinese)
12 Yan J, Pan Q L, Li B et al. Journal of Alloys and Compounds[J], 2015, 632: 549

13 Liao H C, Wu Y N, Zhou K X et al. Materials and Design[J], 2015, 65: 1091

14 Lin Gaoyong, Zhou Jia, Sun Liping et al. Materials Science and Technology[J], 2009, 17(3): 441 (in Chinese)

15 Lin Gaoyong, Zhou Jia, Zhang Zhenfeng et al. Hot Working Technology[J], 2007, 36(13): 9 (in Chinese)

16 Lin Y C, Chen M S, Zhong J. Journal of Materials Processing Technology[J], 2008, 205(1-3): 308

17 Li M Q, Pan H S, Lin Y Y et al. Journal of Materials Processing Technology[J], 2007, 183(1): 71

18 Sajadifar S V, Yapici G G. Journal of Materials Engineering and Performance[J], 2014, 23(5): 1834

19 Zhang C, Zhang L W, Shen W F et al. Journal of Materials Engineering and Performance [J], 2015, 24(1): 149

20 Prasad Y V R K, Seshacharyulu T. International Materials Reviews[J], 1998, 43(6): 243

21 Lin Y C, Li L T, Xia Y C et al. Journal of Alloys and Compounds[J], 2013, 550: 438

22 Luo J, Li M Q, Li H et al. Materials Science and Engineering $A[\mathrm{~J}], 2009$, 505(1-2): 88

\title{
利用本构方程和加工图表征 BFe10-1-2 白铜合金的热变形行为
}

\author{
蔡 军, 王快社, 王 文 \\ (西安建筑科技大学 陕西省冶金工程技术研究中心，陕西 西安 710055)
}

\begin{abstract}
摘 要: 为了获得BFe10-1-2白铜合金的合理热变形工艺参数, 通过热模拟压缩试验对该合金的高温变形行为进行了研究。试验温度为 1023 1273 K, 应变速率为0.001 10 $\mathrm{s}^{-1}$ 。通过流变曲线分析、动力学分析及加工图对BFe10-1-2白铜合金的高温变形行为进行了表征, 计 算出BFe10-1-2白铜合金在热压缩变形过程中的激活能为 $425.299 \mathrm{~kJ} / \mathrm{mol}$ 。通过Zener-Holloman参数以及真应变建立了 BFe10-1-2白铜合金 的本构方程用以描述该合金的高温流动应力。对计算的流动应力值与试验值进行了对比，结果表明：本构方程可以准确描述该合金的高 温流动行为。此外，基于动态模型，建立了BFe10-1-2白铜合金的热加工图，并通过宏观及微观组织分析对加工图的准确性进行了验证。
\end{abstract} 关键词: $\mathrm{BFe} 10-1-2$ 白铜合金; 高温变形行为; 本构方程; 加工图

作者简介: 蔡 军, 男, 1977 年生, 博士, 讲师, 西安建筑科技大学冶金工程学院, 陕西 西安 710055, 电话: 029-82202938, E-mail: caijun@xauat.edu.cn 